\title{
TEKNIK MENGHITUNG FEKUNDITAS TELUR IKAN PAPUYU (Anabas testudineus) DI DANAU PANGGANG DAERAH ALIRAN SUNGAI BARITO, KALIMANTAN SELATAN
}

\author{
Burnawi') \\ 1) Teknisi Litkayasa pada Balai Riset Perikanan Perairan Umum, Mariana-Palembang \\ Teregristasi I tanggal: 12 Desember 2005; Diterima setelah perbaikan tanggal: 10 Mei 2006; \\ Disetujui terbit tanggal: 27 Maret 2007
}

\section{PENDAHULUAN}

Sungai Barito merupakan salah satu sungai terpanjang dan terbesar di Pulau Kalimantan, bagian hulu terletak di Serawak Negara Malaysia dan bagian Hilir terletak di Propinsi Kalimantan Selatan.

Ikan papuyu (Anabas testudineus) merupakan jenis ikan ekonomis penting di perairan umum. Ikan ini hidup dan berkembang biak secara alami terutama di rawa lebak di Pulau Sumatera dan Kalimantan. Ikan papuyu (Anabas testudineus) ini di Pulau Sumatera sering disebut ikan betok (Climbing perches).

Ikan papuyu merupakan ikan konsumsi yang sangat digemari oleh masyarakat Kalimantan Selatan khususnya dan ini bernilai jual tinggi dengan harga di tingkat nelayan berkisar Rp.8.000,- sampai dengan 10.000 ,- per $\mathrm{kg}$.

Studi aspek biologi ikan tentang fekunditas ikan yang berhubungan erat dengan populasi ikan di suatu perairan sangat penting, karena berguna untuk pengelolaan sumber daya ikan tersebut. Untuk mendapatkan data tersebut, teknik-teknik pengambilan, pengawetan dan penghitungan telur ikan yang benar dan akurat diperlukan. Tulisan ini memuat proses yang berkaitan dengan fekunditas ikan papayu.

\section{BAHAN DAN METODE}

Sampel ikan papuyu (Anabas testudineus) diambil dari Danau Panggang, Kabupaten Hulu Sungai Utara Kalimantan Selatan (Gambar 1) pada tahun 2004. Sample ikan diamati di Laboratorium Biologi Balai Riset Perikanan Perairan Umum Palembang.

Penghitungan fekunditas (jumlah telur) dilakukan dengan metode gravimetri yang dikembangkan oleh Effendi (1992). Teknik menghitung fekunditas telur ikan papuyu mencakup beberapa pokok bahasan bahan, alat, dan prosedur kerja antara lain:

\section{Bahan}

Bahan yang digunakan adalah air, formalin $40 \%$, larutan gillson, gonad ikan papuyu (Anabas testudineus), dan kertas kalkir.

\section{Alat}

Alat yang digunakan meliputi petridish, mikroskop, pensil 2B, papan ukur, talenan, botol contoh, kertas saring, dessecting set, baskom dan ember, cool box, timbangan dengan ketelitian $0,01 \mathrm{~g}$, timbangan dengan ketelitian $0,1 \mathrm{~g}$, dan counter.

\section{TEKNIK PENGHITUNGAN FEKUNDITAS}

Ikan papuyu (Anabas testudineus) dari danau panggang ditimbang bobotnya, dan disimpan dalam kantong plastik yang berisi formalin $40 \%$ dan diberi label ikan tersebut. Di Laboratorium, Ikan tersebut diambil gonadnya dan dikemudian diawetkan dengan cara sebagai berikut:

1. Ikan papuyu diletakkan di atas talenan atau di lantai kayu yang datar, kemudian dibedah bagian perut mulai dari pangkal sirip dada secara memanjang sampai dengan ke anus.

2. Pembedahan ini dilakukan memakai pisau bedah atau gunting, ketika membedah perut ikan tersebut dilakukan secara hati-hati supaya tidak melukai gonad ikan sehingga telur tidak keluar dari kantong telur.

3. Gonad ikan dipotong memakai pisau bedah atau gunting, mulai dari bagian pangkal gonad dan kemudian dimasukkan ke dalam botol contoh yang diberi cairan gillson sampai dengan seluruh gonad ikan tersebut terendam dalam cairan gillson tersebut, adapun fungsi larutan gillson untuk sebagai bahan pengawet gonad (telur ikan).

4. Dibuat catatan ditulis di kertas kalkir yang ditulis memakai pensil 2B, catatan tersebut antara lain berisi nomor urut atau kode, nama ikan, ukuran panjang ikan, ukuran bobot ikan, bobot gonad, tempat penangkapan dan tanggal pengambilan contoh, kemudian catatan tersebut dimasukkan dalam botol contoh, ditutup dengan rapat, dan pada akhirnya botol contoh tersebut disimpan dalam cool box.

Setelah diawetkan, gonad ikan dapat dihitung dengan mengikuti prosedur sebagai berikut:

1. Gonad ikan dikeluarkan dalam botol contoh dibawa ke laboratorium lalu dimasukkan ke dalam petridish untuk dilakukan pencucian dengan air dan dibilas 3 kali sampai dengan bau gillson hilang. 
2. Gonad diletakan di atas kertas saring kemudian dimasukkan dalam petridish dan dibiarkan atau dikeringanginkan selama \pm 10 menit.

3. Setelah pengeringan gonad lalu ditimbang menggunakan timbangan dengan ketelitian 0,01 $g$ dengan tujuan untuk mengetahui bobot gonad ikan per ekor.

4. Untuk mengetahui fekunditas mutlak, gonad bagian kanan dan gonad bagian kiri dipotong menjadi 3 bagian yakni pangkal, tengah, ujung, dan masing-masing bagian diambil 3\% lalu dimasukkan dalam petridish.

5. Setiap butiran telur dipisahkan dari selaput telur dan kantong telur memakai alat pinset kemudian telur dihitung satu persatu dibantu dengan alat counter.

6. Setelah diketahui jumlah telur pada masingmasing bagian gonad, maka hasil perhitungan telur tersebut dipersentasikan dengan jumlah bobot total telur dan dicatat dalam bentuk tabulasi untuk perhitungan selanjut.

Hasil pengitungan fekunditas telur ikan papuyu adalah: untuk berat ikan 20-60 gr mempunyai berat gonad 1,2-2,7 gr dan fekunditas telur 1.982-11.570 butir.

\section{KESIMPULAN}

Ikan papuyu (Anabas testudineus) hasil tangkapan nelayan di Danau Panggang Kabupaten Hulu Sungai Utara, Kalimantan Selatan dengan kisaran bobot 20 $60 \mathrm{~g}$ mempunyai kisaran berat gonad 1,2 - 2,7 g dan jumlah telur 1.982 - 11.570 butir.

\section{DAFTAR PUSTAKA}

Effendi, I. M. 1992. Metode biologi perikanan.

Penerbit Yayasan Agromedia. Jakarta.

\section{UCAPAN TERIMA KASIH}

Penulis mengucapan terima kasih sebesarbesarnya pada Bapak Drs. Asyari, Rupawan, S.E. yang telah memberi saran dan koreksi, dan Dewan Redaksi serta pengetik naskah sehingga terlaksana tulisan ini. 